\title{
HBcrAg and Hiv Seroprevalence Among Apparently Healthy Blood Donors In Federal Medical Centre Nguru, Yobe State, Nigeria.
}

\author{
N.C.J. Anyanwu* \\ Department of Microbiology, Faculty of Sciences, Ahmadu Bello University, Zaria, Nigeria.
}

\begin{abstract}
This cross sectional study was aimed at determining HBcrAg and HIV seroprevalence among apparently healthy blood donors in Federal Medical Centre Nguru, Yobe State, Nigeria. Blood samples were collected from 420 apparently healthy blood donors and analyzed for HIV using Determine test kit (Abbott, U.S.A), Uni-Gold test kit (Trinity Biotech, U.S.A) and confirmed using western blot. HBcrAg analysis was done using Lumipulse $f$ CLEIA HBcrAg assay kit (Fujirebio, Japan). Out of the 420 screened blood samples, 30 (7.1\%) were seropositive to HBcrAg while $18(4.30 \%)$ were seropositive to HIV. The association of HIV and HBcrAg seropositivity in relation to age was not statistically significant $(P>0.05)$ for age group 21-30 years. Infection with HIV was highest in age group 21-40 years.
\end{abstract}

Keywords: HBcrAg; HIV; Seroprevalence; Hepatitis B; CLEIA; Nguru.

\section{Introduction}

Screening for anti HBV and HIV antibodies prior to blood donation from voluntary and nonremunerated blood donors has significantly decreased the number of reported cases Hepatitis B and Human Immunodeficiency Virus infections through blood transfusion. However, inadequate screening techniques and false negative results could pose a hitch to this success.

Hepatitis B virus (HBV) is a DNA virus which belongs to the family of viruses Hepadnaviridae (Schwalbe et al, 2008). It forms stable circular covalently closed (ccc) DNA that can persist in the liver indefinitely. HBV is the leading cause of chronic liver disease and liver-related death worldwide, with the majority of these cases occurring in areas of Africa and Asia where HBV prevalence is high (Hoffmann and Thio, 2007). Individuals with evidence of past infection (core antibody positivity) are at risk of HBV reactivation, particularly in the setting of severe immunocompromise, prolonged steroid use or chemotherapy (Luetkemeyer, 2010).

The Human Immunodeficiency Virus (HIV) is a retrovirus that primarily infects components of the human immune system such as $\mathrm{CD} 4^{+} \mathrm{T}$ cells, macrophages and dendritic cells, directly or indirectly destroying $\mathrm{CD}^{+} \mathrm{T}$ cells, leading to spectrum of disease known as HIV/AIDS (Alimonti et al., 2003).

Co-infections with HIV and HBV are common with $70-90 \%$ of HIV-infected individuals in the United States having evidence of past or active infection with HBV (Luetkemeyer, 2010). Coinfection rates are highest among men who have sex with men, and injection drug users. In contrast, in Asia and Sub-Saharan Africa, where vertical and early childhood exposure are the most common modes of transmission respectively, and overall HBV prevalence is higher, the prevalence of HBV among HIV-infected individuals also is higher, at an estimated 20-30\% (Luetkemeyer, 2010).

This study was aimed at determining HBcrAg and HIV seroprevalence among apparently healthy blood donors in Federal Medical Centre Nguru, Yobe State, Nigeria.

\section{Materials And Methods}

Study Population and Ethical consent

Four hundred and twenty blood samples were randomly collected from apparently healthy male and female donors in Federal Medical Centre, Nguru, Yobe State between November 2012 to June 2013 and screened. Donors between ages of 21-50 years were included. Only donors having a history of jaundice in preceding year, I/V drug abuse stigma, low weight, fever, low hemoglobin or less and more than desirable age were excluded. Approval for the study was obtained from the hospital and informed consent was obtained from the donors.

\section{Sample Collection and Processing}

Using a sterile disposable syringe, $3 \mathrm{ml}$ of venous blood was collected aseptically by a clinician and dispensed into a plain sterile sample bottles and transported safely to the laboratory. The blood samples were 
centrifuged at 2,500 rpm and sera collected into clean, sterile dry plain sample bottles using a clean dry Pasteur pipette. The sera were stored at $-20^{\circ} \mathrm{C}$ until needed for analysis (Cheesbrough, 2000).

Analysis of Sera for anti-HIV-1 and HIV-2 was conducted using Determine ${ }^{\mathrm{TM}}$ test kit (Abbott Laboratories, U.S.A). The samples that were reactive with Determine were retested using the Uni-Gold ${ }^{\mathrm{TM}}$ Recombigene ${ }^{\circledR}$ test kit (Trinity Biotech, U.S.A) and then confirmed by western blotting. Screening was done according to the manufacturers' instructions. Controls provided by manufacturer and external controls were used.

Hepatitis B core related antigen ( $\mathrm{HBcrAg}$ ) was detected using Lumipulse $\mathrm{f}$ Chemilumiscence EIA (CLEIA) assay (Fujirebio, Japan) as instructed by manufacturer. HBcrAg uses HB91 and HB110 monoclonal antibodies as detector antibodies that react with denatured Hepatitis B core antigen $(\mathrm{HBcAg})$ and Hepatitis B envelope antigen $(\mathrm{HBeAg})$, thus the assay detects precore and core proteins. It contains a pretreatment step that inactivates antibodies and dissociates antigens in samples, thus detecting antigens within the viral envelope or complexed with antibodies in addition to free antigens. Hence, it is adequate for testing HBeAg negative chronic hepatitis.

\section{Data Analysis}

Results of the laboratory analysis were analyzed using SPSS version 17 at $95 \%$ confidence interval (CI) and presented in tables.

The prevalence of each viral infection (HBcrAg and HIV) and co-infection was determined from the proportion of seropositive individuals in the total population under consideration and expressed as a percentage.

\section{Results}

Result obtained showed an overall prevalence of HBV, HIV, and co-infection to be $7.1 \%, 4.3 \%$, and $2.9 \%$ respectively. Out of the 420 blood samples obtained from blood donors, 86.7\% (364/420) were males while $13.3 \%(56 / 420)$ were females.

Of the 364 male donors screened $4.4 \%$ (16/364) and 7.1\% (26/364) were positive for HIV and HBV respectively while co-infection with both virus was $2.7 \%(10 / 364)$. There was statistically significant association $\left(\chi^{2}=38.661, \mathrm{df}=1, \mathrm{p}=0.001\right)$ between male and prevalence of the viruses (Table 1.0). Only 2 out of the 56 female donors $(3.6 \%)$ were co-infected with both viruses. There was a statistically significant association $\left(\chi^{2}=28.00\right.$, $\mathrm{df}=1, \mathrm{p}=0.036$ ) between the female and prevalence of both viruses (Table 2.0).

The result obtained was further analysed based on the different age groups, of the 420 samples obtained, 54, 272 and 94 were within the age group of 21-30 years, 31-40 years and 41-50 years respectively. 4 out of the 54 donors (7.4\%) screened within the age group of 21-30 years were positive for HBV, while 6 (11.1\%) were positive for HIV. Only 3.7\% (2/54) of the donors in age group 21-30 years had co-infection with both HBV and HIV. There was no statistical association $\left(\chi^{2}=3.307, \mathrm{df}=1, \mathrm{p}=0.214\right)$ between the prevalence of both infections in age group 21-30 years (Table 3.0). Of the 272 donors in age groups 31-40 years screened, $3.7 \%(10 / 272)$ were positive for HIV, $8.1 \%(22 / 272)$ were positive for HBV and 2 donors were co-infected with HBV and HIV, $0.74 \%(2 / 272)$. There was statistical association $\left(\chi^{2}=36.106, \mathrm{df}=1, \mathrm{p}=0.001\right)$ between the prevalence of both viruses and age group 31-40 years (Table 4.0).

Two out of 94 donors screened in age groups $41-50$ years were co-infected with both viruses $2.1 \%$ (2/94) while the remaining population in the age group $97.9 \%$ (92/94) had no antibodies for both HBV and HIV (Table 5.0).

Table 1.0 Prevalence of HBV and HIV among Male Donors in FMC, Nguru

\begin{tabular}{|c|c|c|c|c|}
\hline HIV/HBV & & $\begin{array}{l}\text { No. of sample } \\
\text { Positive (\%) }\end{array}$ & $\begin{array}{l}\text { HIV } \\
\text { No. of sample } \\
\text { Negative (\%) }\end{array}$ & Total no. of sample tested \\
\hline \multirow{3}{*}{ HBV } & $\begin{array}{l}\text { No. of sample } \\
\text { positive (\%) }\end{array}$ & $10(38.50)$ & $16(61.50)$ & $26(7.10)$ \\
\hline & $\begin{array}{l}\text { No. of sample } \\
\text { negative }(\%)\end{array}$ & $6(1.80)$ & $332(98.20)$ & $338(92.90)$ \\
\hline & $\begin{array}{l}\text { Total no. of sample } \\
\text { tested }\end{array}$ & $16(4.40)$ & $348(95.40)$ & $364(100.00)$ \\
\hline
\end{tabular}

$(\chi 2=38.661, \mathrm{df}=2, \mathrm{p}=\mathbf{0 . 0 0 1})$

Table 2.0: Prevalence of HIV and HBV among Female Donors in FMC, Nguru

\begin{tabular}{|c|c|c|c|c|}
\hline HIV/HBV & & $\begin{array}{l}\text { No. of sample } \\
\text { Positive (\%) }\end{array}$ & $\begin{array}{l}\text { HIV } \\
\text { No. of sample } \\
\text { Negative }(\%)\end{array}$ & $\begin{array}{l}\text { Total no. of sample } \\
\text { tested }\end{array}$ \\
\hline \multirow{3}{*}{ HBV } & $\begin{array}{l}\text { No. of sample } \\
\text { positive }(\%)\end{array}$ & $2(3.60)$ & $0(0.00)$ & $2(3.60)$ \\
\hline & $\begin{array}{l}\text { No. of sample } \\
\text { negative }(\%)\end{array}$ & $0(0.00)$ & $54(100.00)$ & $54(96.40)$ \\
\hline & $\begin{array}{l}\text { Total no. of sample } \\
\text { tested }\end{array}$ & $2(3.60)$ & $54(96.40)$ & $56(100.00)$ \\
\hline
\end{tabular}


$(\chi 2=28.00, \mathrm{df}=2, \mathrm{p}=\mathbf{0 . 0 3 6})$

Table 3.0: Prevalence of HIV and HBV among blood donors within the ages 21-30years

\begin{tabular}{|c|c|c|c|c|}
\hline HBV/HIV & & $\begin{array}{l}\text { No. of sample } \\
\text { Positive (\%) }\end{array}$ & $\begin{array}{l}\text { HIV } \\
\text { No. of sample } \\
\text { Negative }(\%)\end{array}$ & $\begin{array}{l}\text { Total no. of sample } \\
\text { tested }\end{array}$ \\
\hline & $\begin{array}{l}\text { No. of sample } \\
\text { positive }(\%)\end{array}$ & $2(50.0)$ & $2(50.0)$ & $4(7.4)$ \\
\hline \multirow[t]{2}{*}{ HBV } & $\begin{array}{l}\text { No. of sample } \\
\text { negative }(\%)\end{array}$ & $4(8.0)$ & $46(92.0)$ & $50(92.6)$ \\
\hline & $\begin{array}{l}\text { Total no. of sample } \\
\text { tested }\end{array}$ & 6(11.1) & 48(88.9) & $54(100.0)$ \\
\hline
\end{tabular}

$(\chi 2=3.307, \mathrm{df}=2, p=0.214)$

Table 4.0: Prevalence of HIV and HBV among Blood Donors within the ages 31-40 years

\begin{tabular}{|c|c|c|c|c|}
\hline $\mathrm{HBV} / \mathrm{HIV}$ & & $\begin{array}{l}\text { No. of sample } \\
\text { Positive (\%) }\end{array}$ & $\begin{array}{l}\text { HIV } \\
\text { No. of sample } \\
\text { Negative }(\%)\end{array}$ & $\begin{array}{l}\text { Total no. of sample } \\
\text { tested }\end{array}$ \\
\hline \multirow{3}{*}{ HBV } & $\begin{array}{l}\text { No. of sample } \\
\text { positive }(\%)\end{array}$ & $8(36.3)$ & $14(63.7)$ & $22(8.1)$ \\
\hline & $\begin{array}{l}\text { No. of sample } \\
\text { negative }(\%)\end{array}$ & $2(0.8)$ & $148(99.2)$ & $250(91.9)$ \\
\hline & $\begin{array}{l}\text { Total no. of sample } \\
\text { tested }\end{array}$ & $10(3.7)$ & $262(96.3)$ & $272(100.0)$ \\
\hline
\end{tabular}

$(\chi 2=36.106, \mathrm{df}=2, \mathrm{p}=0.001)$

Table 5.0: Prevalence of HIV and HBV among Blood Donors within the ages 41-50 years

\begin{tabular}{|c|c|c|c|c|}
\hline \multirow[b]{2}{*}{$\mathrm{HBV} / \mathrm{HIV}$} & \multicolumn{4}{|c|}{ HIV } \\
\hline & & No. of sample & No. of sample & Total no. of sample \\
\hline \multirow{3}{*}{ HBV } & $\begin{array}{l}\text { No. of sample } \\
\text { positive }(\%)\end{array}$ & $2(100.0)$ & $0(0.00)$ & $2(2.1)$ \\
\hline & $\begin{array}{l}\text { No. of sample } \\
\text { negative }(\%)\end{array}$ & $0(0.00)$ & $92(100.0)$ & $92(97.9)$ \\
\hline & $\begin{array}{l}\text { Total no. of sample } \\
\text { tested }\end{array}$ & $2(2.1)$ & $92(97.9)$ & $94(100.0)$ \\
\hline
\end{tabular}

$(\chi 2=47.000, \mathrm{df}=2, \mathrm{p}=0.001)$

\section{Discussion}

This study determined the prevalence of HBV and HIV antibodies from 420 apparently healthy blood donors within the ages of 21-50 years in Nguru, Yobe State. The results showed HBV prevalence of 7.1\%, HIV prevalence of $4.3 \%$, and co-infection with both viruses to be $2.9 \%$.

The prevalence of HBV (7.1\%) obtained in this study is slightly lower than $8.3 \%$ obtained in a low resource setting in Nigeria (Eke et al., 2011) and the 9.3\% recorded by Ezegbudo et al., (2004) in Anambra state, Nigeria. It is however, higher than the 5.8\% obtained in Edo State, Nigeria (Umolu et al., 2005), 1.6\% in Rome, Italy, and 1.9\% in Bali, Indonesia (Surya et al., 2005). Factors affecting the prevalence of chronic HBV include age at the time of infection and mode of acquisition which vary geographically (Luetkemeyer, 2010).

The prevalence of HIV (4.3\%) obtained from this study is similar to prevalence of $4.5 \%$ and $4.0 \%$ reported in Nigeria (Sofo et al., 2003: WHO, 2011). The result is lower than 10\% recorded in Edo State and Benue state, Nigeria (Umolu et al., 2005: UNAIDS, 2007). However, the result is higher than less than 2.1\% prevalence obtained in Ekiti state, Jigawa state and Oyo state of Nigeria (UNAIDS, 2007), 0.2\% in Western and Central Europe and $0.1 \%$ in East Asia (UNAIDS, 2011). The variations in the seroprevalence of HBV and HIV may be due to geographical variation, differences in cultural practices, sexual practices, and differences in the techniques employed which agrees with the findings of Olokoba et al., (2011).

This study recorded $2.9 \%$ prevalence of HIV and HBsAg co-infection among blood donors which is lower compared to $11.9 \%$ obtained from a study on a Nigerian cohort of HIV infected patients (Otegbayo et al., 2008), 4.2\% in low resource settings (Eke et al., 2011) and 4.47\% in the US (Kim et al., 2008) and higher than $0.88 \%$ obtained in Bobo Dioulasso, Burkina Faso (Dao et al., 2001) and $1.13 \%$ in Malian blood donors (Tounkara et al., 2009). 
The prevalence of HIV infection was higher in male than in female and this contrast with earlier findings that women are particularly affected with HIV (UNGASS, 2010). The higher prevalence in male than female obtained from this study may be due to differences in the target population, this study sampled blood donors which are predominantly male while earlier studies sampled from the general population. Federal Ministry of Health in 2008 reported more number of female (1.73 Million) infected with HIV than Male (1.2 Million) (FMOH, 2009). Luetkemeyer (2010), however, stated that HIV/HBV coinfection rates are highest among men who have sex with men, and injection drug users.

The prevalence of $11.1 \%$ obtained among donors of age group $21-30$ is higher than the prevalence of $4.6 \%$ and 5.6\% reported for age group 20-24 and 25-29 years respectively by the Federal Ministry of Health, (2009). The highest prevalence of HIV recorded in age group 21-30years (higher than age groups 31-40 and 41-50), may be attributed to the increased rate of unprotected sexual practices among this age group.

The highest prevalence of HBcrAg was obtained in age group 31-40 years. There has been earlier report of prevalence of the surface antigen (HBsAg) in Nigeria being highest within age group of 25-29 years (Olokoba et al., 2011). There was, however, no reported prevalence of the core related antigen (HBcrAg) at the time of this study. The high prevalence of the infection in this age group may be associated to lack of awareness of the mode of transmission of HBV infection.

\section{Conclusion}

The present study established the seroprevalence of HBV, HIV, and co-infection with the two viruses to be $7.1 \%$, $4.3 \%$, and $2.9 \%$ respectively among apparently healthy blood donors in Nguru. Chemilumiscence EIA HBcrAg assay was used for HBV screening to eliminate instances of HBeAg negative chronic hepatitis. The high prevalence of HBV could be attributed to the modes of transmission of the virus.

Screening for both HIV and HBV among the populace will help reduce the risk of transmission of both viruses. Mass vaccination programmes should be embarked upon for those that do not have antibodies for HBV and treatment of infected persons should be commenced upon detection of antibodies to the virus. Awareness should also be made on the mode of transmission of these viruses.

\section{References}

[1]. Alimonti, J.B., Ball, T.B., Fowke, K.R. (2003). Mechanisms of CD4+ T lymphocyte cell death in human immunodeficiency virus infection and AIDS. Journal of General Virology 84 (7): 1649-1661.

[2]. Cheesbrough, M. (2000).District laboratory practice in tropical countries (Part 2).Cambridge University press, USA. pp 248 - 266.

[3]. Dao, B., Nacro, B., Dahorou, H., Meda, N. and Van De Perre, P. (2001). HIV infection and hepatitis B coinfection: survey of prevalence in pregnant women in Bobo Dioulasso, Burkina Faso. Brussels Review of Medicine, 22:83-86.

[4]. Eke, A.C., Eke, U.A., Okafor, I.C., Ezebialu, I.U. and Ogbuagu, C. (2011). Prevalence, correlates and pattern of hepatitis B surface antigen in a low resource setting. Virology Journal 2011,8: 8-12.

[5]. Ezegbudo, C.N., Agbonlahor, D.E., Nwobu, G.O., Igwe, C.U., Agba, M.I. and Okpala H.O. (2004). The seroprevalence of hepatitis $\mathrm{B}$ surface antigen and human immunodeficiency virus among pregnant women in Anambra State, Nigeria. Shiraz E-Medical Journal, 5:1-9.

[6]. Federal Ministry of Health, Nigeria (2009). Report on the 2008 National HIV seroprevalence sentinel survey among pregnant women attending antenatal clinics in Nigeria. 1-46.

[7]. Hoffmann, C.J., Thio, C.L. (2007). Clinical implications of HIV and hepatitis B co-infection in Asia and Africa. Lancet Infectious Diseases, 7:402-409.

[8]. Kim, J.H., Psevdos ,G., Suh, J., and Sharp, V.L. (2008). Co-infection of hepatitis B and hepatitis C virus in human immunodeficiency virus-infected patients in New York City, United States. World Journal of Gastroenterology, 14: 6689-6693.

[9]. Luetkemeyer, A. (2010). Hepatitis B and HIV co-infection. Project of HIV in-site knowledge centre in UCSF. University of California. Pp 1-10.

[10]. Olokoba, A.B., Salawu, F.K., Danburam, A., Olokoba, L.B., Midala, J.K., Badung, L.H., and Olatinwo, A. (2011). Hepatitis B virus infection amongst pregnant women in North-Eastern Nigeria- A call for action. Nigerian Journal of Clinical Practise, 14:10-13.

[11]. Otegbayo, J.A., Taiwo, B.O., Akingbola, T.S., Odaibo, G.N., Adedapo, K.S.,Penugonda,S.,Adewole, I.F., Olaleye, D.O., Murphy, R. and Kanki, P. (2008). Prevalence of hepatitis B and C seropositivity in a Nigerian cohort of HIV-infected patients. Annals of Hepatology, 7:152-156.

[12]. Schwalbe, M., Ohlenschlager, O., Marchanka, A., (2008). Solution structure of stem-loop alpha $\quad$ of the hepatitis B virus posttranscriptional regulatory element" Nucleic Acids Research 36(5): 1681-9.

[13]. Surya, I.G., Kornia, K., Suwardwea, T.G., Mulyanto, T.F. and Mishiro, S.(2005). Serological markers of hepatitis B, C, and E virus and human immunodeficiency virus type-1 infections in pregnant women in Bali, Indonesia. Journal of Medical Virology,75:499- 503.

[14]. Sofo, C.A. Ali A. and Toni p. (2003). Social development and poverty in Nigeria. Chapter 3 in $\quad$ Measuring poverty in Nigeria', Oxfam Working Paper.

[15]. Tounkara, A., Sarro, Y.S., Kristensen, S., Dao, S., Diallo, H., Diarra, B., Noumsi, T.G. and Guindo, O. (2009).Seroprevalence of HIV and HBV coinfection in Malian blood donors. Journal of the International Association of Physicians in Aquired Immunedeficiency Syndrome Care, 8:47-51.

[16]. Umolu, P.I., Okoror, E.L., Orhue, P. (2005). HIV seropositivity and HBsAg among blood donors in Benin city, Edo state, Nigeria. African Health Sciences. 5(1):55-58.

[17]. UNAIDS, WHO (2007). "2007 AIDS epidemic update" (PDF). http://data.unaids.org/pub/EPI-Slides/2007/2007_epiupdate_en.pdf

[18]. UNAIDS (2011). Joint United Nations Programme on HIV/AIDS . Global HIVIAIDS Response, Epidemic update and health sector progress towards universaaccess.http://www.unaids.org/en/media/unaids/contentassets/documents/unaidsp ublication/2011/20111130 UA Report en.pdf.

[19]. UNGASS (2010). HIV/AIDS prevalence rate in Nigeria, http://www.unaids.org/en/countrresponses/-countries/nigeria.asp

[20]. WHO (2011). Global HIV/AIDS Response: Epidemic update and health sector progress towards $\quad$ Universal Access 2011, http://www.who.int/hiv/pub/progress_report2011/en/index.html. 